\title{
Sequence, localization and characteristics of the replicator region of the symbiotic plasmid of Rhizobium etli
}

\author{
Miguel A. Ramírez-Romero, ${ }^{1} \dagger$ Patricia Bustos, ${ }^{1}$ Lourdes Girard, ${ }^{1}$ \\ Oscar Rodríguez, ${ }^{1}$ Miguel A. Cevallos ${ }^{2}$ and Guillermo Dávila'
}

\author{
Author for correspondence: Guillermo Dávila. Tel: +5273133881 . Fax: +5273175581. \\ e-mail:davila@cifn.unam.mx
}

Departamento de Genética Molecular ${ }^{1}$ and Departamento de Ecología Molecular2, Centro de Investigación sobre Fijación de Nitrógeno, Universidad Nacional Autónoma de México, Apartado Postal 565-A, Cuernavaca, Morelos, Mexico

\begin{abstract}
The replicator region of the symbiotic plasmid of Rhizobium etli CFN42 was cloned and sequenced. A plasmid derivative (pH3) harbouring a $5.6 \mathrm{~kb}$ Hind III fragment from the symbiotic plasmid was found to be capable of independent replication and eliminated the symbiotic plasmid when introduced into a $R$. etli CFNX101 strain (a recA derivative). The stability and the copy number of pH3 were the same as that of the symbiotic plasmid, indicating that the information required for stable replication and incompatibility resides in the $5.6 \mathrm{~kb}$ Hind III fragment. The sequence analysis of this fragment showed the presence of three ORFs similar in sequence and organization to repA, repB and repC described for the replicator regions of the Agrobacterium plasmids pTiB6S3 and pRiA4b and for the R. leguminosarum cryptic plasmid pRL8J. Hybridization studies showed that p42d-like replicator sequences are found in the symbiotic plasmids of other $R$. etli strains and in a 'cryptic' plasmid of R. tropici.
\end{abstract}

Keywords: symbiotic plasmid, plasmid replication, Rhizobium etli

\section{INTRODUCTION}

The bacterial genera Rhizobium and Sinorhizobium belong to the family Rhizobiaceae and are able to form nitrogen-fixing nodules with several legume species. Members of the genus Agrobacterium of the same family also interact with plants but induce pathogenic responses in plants, such as crown-gall or hairy-root diseases. A distinctive characteristic of these organisms is the huge amount of genetic information encoded in large plasmids of low copy number. Calculations based on assumed sizes of chromosomes indicate that the plasmid pool may represent between 25 and $50 \%$ of the genome (Martínez et al., 1990; García-de los Santos et al., 1996). It is well established that many of the bacterial genes governing plant-microbe interactions are plasmid-borne. In Rhizobium spp. many of the genes involved in nodulation and nitrogen fixation lie on a single plasmid, the symbiotic plasmid or pSym. How-

\footnotetext{
†Present address: Departamento de Immunología, Instituto de Investigaciones Biomédicas, Universidad Nacional Autónoma de México, Ciudad Universitaria, D.F., Mexico.

The GenBank accession number for the nucleotide sequence reported in this paper is U80928.
}

ever, pSym coexists with 1-10 so-called 'cryptic' plasmids. Information accumulated over many years indicates that cryptic plasmids may harbour genes involved in basic metabolic functions, utilization of nutrients and synthesis of cellular components (Garcíade los Santos et al., 1996). It has been shown that some Rhizobium plasmids are transmissible or mobilizable by other plasmids under laboratory conditions or in media resembling soil (Johnston et al.. 1982; O'Connell et al., 1987; Mercado-Blanco \& Olivares, 1993; Kinkle \& Schmidt, 1991). Studies of population genetics of rhizobia based on chromosomal and plasmid characteristics suggest that horizontal gene transfer occurs in natural populations (Schofield et al., 1987; Young \& Wexler, 1988).

Incompatibility has been observed between Rhizobium plasmids (including symbiotic plasmids) (Beynon et al., 1980; O'Connell et al., 1984; Hooykaas et al., 1985) and between Rhizobium and Agrobacterium plasmids (including pTi and pRi plasmids) (O'Connell et al., 1987; Hynes et al., 1985). Some Rhizobium strains containing two symbiotic plasmids with the same or different hostrange determinants have been constructed, indicating that the symbiotic plasmids can belong to different incompatibility groups (Hooykaas et al., 1981; Geniaux 
Table 1. Bacterial strains and plasmids used in this work

\begin{tabular}{|c|c|c|}
\hline Strain or plasmid & Relevant characteristics* & Reference or source \\
\hline \multicolumn{3}{|l|}{ Rhizobium spp. } \\
\hline CIAT895 & Wild-type, nodulates Phaseolus vulgaris & Pinero et al. (1988) \\
\hline \multicolumn{3}{|c|}{$r_{1}$} \\
\hline VIKING1 & Wild-type, nodulates $P$. vulgaris & Pinero et al. (1988) \\
\hline TAL182 & Wild-type, nodulates $P$. vulgaris & Pinero et al. (1988) \\
\hline BRA5 & Wild-type, nodulates $P$. vulgaris & Pinero et al. (1988) \\
\hline NITRAGIN8251 & Wild-type, nodulates $P$. vulgaris & Pinero et al. (1988) \\
\hline CFN42 & Wild-type (type strain), nodulates $P$. vulgaris & Quinto et al. (1982) \\
\hline CE3 & $\mathrm{Sm}^{\mathrm{r}}$ derivative of CFN42 & Noel et al. (1984) \\
\hline CFNX101 & $\operatorname{rec} A:: \Omega, \mathrm{Sp}^{\mathrm{r}} \mathrm{Sm}^{\mathrm{r}}$ derivative of $\mathrm{CE} 3$ & Martínez-Salazar et al. (1991) \\
\hline CFNX107 & $\operatorname{rec} A:: \Omega, \mathrm{Sp}^{\mathrm{r}} \mathrm{Sm}^{\mathrm{r}}, \mathrm{p} 42 \mathrm{a}^{-}, \mathrm{p} 4 \mathrm{~d}^{-}$derivative of CE3 & Martínez-Salazar et al. (1991) \\
\hline \multicolumn{3}{|c|}{${ }^{-1}$} \\
\hline CCBAU2605 & Wild-type, nodulates Astragalus sinicus & N. Novikova, St Petersburg, Russia \\
\hline \multicolumn{3}{|c|}{ 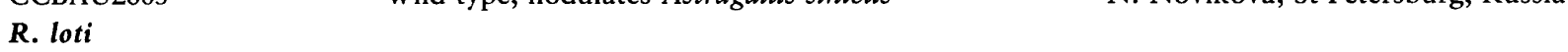 } \\
\hline CIAM1801 & Wild-type, nodulates Lotus & N. Novikova, St Petersburg, Russia \\
\hline \multicolumn{3}{|c|}{ R. leguminosarum bv. viciae } \\
\hline VF39 & Wild-type, nodulates Vicia faba & Hynes et al. (1988) \\
\hline \multicolumn{3}{|l|}{ R. tropici } \\
\hline CFN299 & Wild-type, nodulates $P$. vulgaris & Pinero et al. (1988) \\
\hline \multicolumn{3}{|l|}{ S. meliloti } \\
\hline 2011 & Wild-type, $\mathrm{Sm}^{\mathrm{r}}$, nodulates Alfalfa & Casse et al. (1979) \\
\hline \multicolumn{3}{|l|}{ A. tumefaciens } \\
\hline GMI9023 & C58, plasmid-less derivative & Rosenberg \& Hughet (1984) \\
\hline \multicolumn{3}{|l|}{ E. coli } \\
\hline HB101 & Host strain for plasmids & Boyer \& Roulland-Dussoix (1969) \\
\hline DH5 $\alpha$ & Host strain for plasmids & Hanahan (1983) \\
\hline \multicolumn{3}{|l|}{ Plasmid } \\
\hline pBluescript II SK + & $A p^{r}$, cloning vector, ColE1 origin of replication & Stratagene \\
\hline pSUP202 & $\begin{array}{l}\mathrm{Ap}^{\mathrm{r}} \mathrm{Cm}^{\mathrm{r}} \mathrm{Tc}^{\mathrm{r}} \text {, ColE1 origin unable to replicate in } \\
\text { Rhizobium spp. }\end{array}$ & Simon et al. (1983) \\
\hline cGD47 & $\begin{array}{l}\text { Lorist } 3 \mathrm{~B} \text { cosmid derivative containing } \mathrm{BamHI} \\
\text { fragments } 72-80 \text { of the structural map of } \mathrm{p} 42 \mathrm{~d}\end{array}$ & Girard et al. (1991) \\
\hline pB79 & $\begin{array}{l}\text { pSUP202 derivative containing BamHI fragment } \\
79 \text { of the structural map of } \mathrm{p} 42 \mathrm{~d} \text {; contains the } \\
\text { replicator region of } \mathrm{p} 42 \mathrm{~d}\end{array}$ & This work \\
\hline $\mathrm{pH} 3$ & $\begin{array}{l}\text { pSUP202 derivative containing a HindIII fragment } \\
\text { of } 5.6 \mathrm{~kb} \text { containing the replicator region of p } 42 \mathrm{~d}\end{array}$ & This work \\
\hline pRK2013 & Helper plasmid, $\mathrm{Km}^{\mathrm{r}}$ & Ditta et al. (1980) \\
\hline
\end{tabular}

*Ap, ampicillin; Cm, chloramphenicol; Km, kanamycin; Sm, streptomycin; Sp, spectinomycin; Tc, tetracycline.

\& Amarger, 1993). Incompatibility is linked to common replication functions and should reflect a close ancestral relationship between plasmids (O'Connell et al., 1987).

Diverse types of rearrangements within plasmids (amplifications, deletions and translocations) and recombination between different plasmids have been described for Rhizobium (Romero et al., 1997; Johnston et al., 1982). These phenomena, coupled to the transmissibility of plasmids between different Rhizobium species, are partially responsible for the large genetic diversity observed within the Rhizobiaceae.

The study of the molecular basis of incompatibility, stability and replication of plasmids may help us to understand one important factor directing the flux of information between members of the Rhizobiaceae. With this aim, we report here the isolation and molecular characterization of the replicator region of the symbiotic plasmid of Rhizobium etli CFN42. This constitutes the first description of a symbiotic replicator within the Rhizobiaceae.

\section{METHODS}

Bacterial strains and growth conditions. The bacterial strains used in this work are listed on Table 1. Rhizobium strains were grown at $30^{\circ} \mathrm{C}$ in PY medium (Noel et al., 1984). Escherichia coli strains were grown at $37^{\circ} \mathrm{C}$ in Luria-Bertani medium. Antibiotics were supplemented at the following 


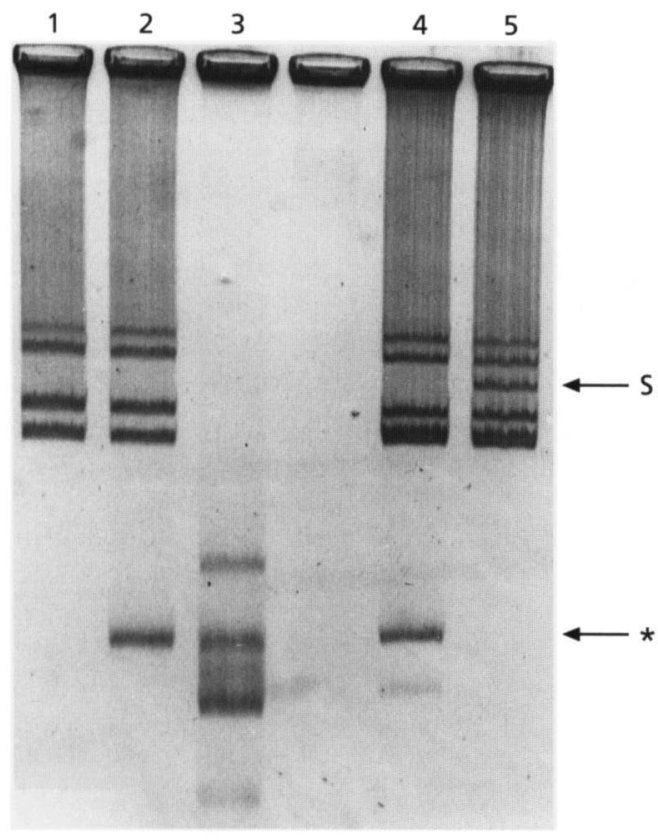

Fig. 1. Plasmid profiles of CFNX107 (lane 1), CFNX107 (pH3) (lane 2), DH5 $\alpha(\mathrm{pH} 3)$ (lane 3), CFNX101(pH3) (lane 4) and CFNX101 (lane 5). The arrow labelled ' $S$ ' indicates the position of the symbiotic plasmid p42d. The arrow labelled ' $*$ ' indicates the position of $\mathrm{pH} 3$.

concentrations $\left(\mu \mathrm{g} \mathrm{ml}^{-1}\right)$ : nalidixic acid, 20; tetracycline, 10; kanamycin, 30; chloramphenicol, 25; ampicillin, streptomycin, rifampicin or spectinomycin, 100.

Plasmid profiles. High molecular mass plasmids were visualized by the procedure described by Wheatcroft et al. (1990) (see Fig. 1).

Mobilization of cosmids to Rhizobium strains. To mobilize a set of cosmids derived from Lorist 3B, a non-mobilizable vector unable to replicate in Rizobium, it was necessary to make a co-integrate between each cosmid and a mobilizable vector. For this purpose a pSUP202 derivative containing a $3.8 \mathrm{~kb}$ Pst I fragment of Lorist 3B was constructed to provide regions of homology between pSUP202 and the cosmids. This construction was transformed into $E$. coli strains containing the cosmid and the co-integrates were mobilized to Rhizobium in triparental matings using pRK2013 as helper plasmid (Ditta et al., 1980).

DNA sequencing. XhoI, EcoRI, SalI and Pst I fragments of the DNA insert of clone $\mathrm{pH} 3$ were subcloned in the pBluescript II $\mathrm{SK}+$ phagemid vector (Stratagene) and transformed into $E$. coli DH5 $\alpha$. Double-stranded DNA was isolated and sequenced with a combination of universal primer and custom-made oligonucleotide primers using the Taq DyeDeoxy Terminator Cycle Sequencing Kit and 373A DNA Sequencing System (Applied Biosystems).

Analysis of nucleotide and amino acid sequences. Nucleic acid sequence data and deduced amino acid sequences were analysed with the GeneWorks package (release 2.5; IntelliGenetics). Similarity searches with the GenBank and EMBL databases were made using the FASTA, TFASTA, BLASTN and BLASTX programs, which are part of the Wisconsin Sequence
Analysis Software Package (Genetic Computer Group Package, version 8 ).

Plasmid stability. Plasmid stability was calculated according to the procedure described by Durland et al. (1987). Briefly, stationary phase cultures were diluted in fresh medium without selection to give an initial $O_{620}$ of 0.001 and cultivated for 9,18 and 31 generations. Samples taken at these times were serially diluted and plated on solid media in the absence of selective drugs. One hundred colonies were chosen and picked onto plates with and without the selective antibiotic. The percentage of plasmid loss per generation was calculated with the formula: percentage plasmid loss per generation $=\left[1-\left(F_{n} / F_{0}\right)^{1 / n}\right] / 100$, where $F_{n}$ is the antibioticresistant cell fraction after $n$ generations and $F_{0}$ is the initial fraction of resistant cells.

DNA isolation, manipulation and hybridization. Genomic and plasmid DNA were isolated as described in Sambrook et al. (1989). DNA was restricted and ligated under the conditions specified by the enzyme manufacturer (Amersham). DNA restriction fragments were separated for hybridization by electrophoresis in $1 \%$ agarose gels, transferred onto Hybond-N membranes (Amersham) and cross-linked in vacuum at $80^{\circ} \mathrm{C}$. Hybridizations were performed overnight using $\left[\alpha^{\mathbf{3 2}} \mathrm{P}\right] \mathrm{dCTP}$-labelled probes (Megaprime Kit, Amersham) and high stringency conditions $\left(65^{\circ} \mathrm{C}\right.$ in sodium phosphate buffer $)$. Hybridization signals were detected on X-OMAT-K film (Kodak) in the presence of intensifying screens.

Determination of plasmid copy number. A DNA blot containing genomic DNA of strains CE3, CFNX101(pH3) and CFNX107(pH3), restricted with HindIII, was hybridized simultaneously with a $1 \mathrm{~kb}$ fragment of the chromosomally encoded gene $\mathrm{rec} A$ and with an internal $1 \mathrm{~kb}$ fragment of $\mathrm{pH} 3$. Both probes were labelled at the same specific radioactivity. The recA probe and $\mathrm{pH} 3$ probe hybridized with a $1.2 \mathrm{~kb}$ and a $1.4 \mathrm{~kb}$ HindIII fragment, respectively. Hybridization signals were integrated by scanning the autoradiographs with a GS300 scanning densitometer using the GS365W data system (Hoefer Scientific Instruments), taking care that measurements were within the linear range of the film. Plasmid copy number was calculated as the ratio of the integrated hybridization signal of the symbiotic plasmid $(\mathrm{pH} 3)$ and the integrated hybridization signal of the chromosome probe.

\section{RESULTS AND DISCUSSION}

\section{Cloning of the replicator region of symbiotic plasmid p42d}

R. etli CFN42 (type strain) contains six large plasmids. The symbiotic plasmid ( $\mathrm{p} 42 \mathrm{~d}$ ) of $390 \mathrm{~kb}$ contains many of the nif, fix and nod genes and confers nodulation proficiency when transferred to Agrobacterium tumefaciens (Martínez et al., 1990). A structural map of this plasmid has been assembled from an ordered cosmid collection, comprising $85 \mathrm{BamHI}$ fragments, which were numbered consecutively on the circular map from an arbitrary start in the nifHDK region 'a' (Girard et al., 1991) (Fig. 2). To isolate the replicator region of p42d, a set of cosmids covering the entire symbiotic plasmid (Girard et al., 1991) was transferred by conjugation to strains CFNX107 and CE3 as described in Methods. CFNX107 was utilized to reduce stabilization of the cosmids by integration, since plasmids $\mathrm{p} 42 \mathrm{a}$ and $\mathrm{p} 42 \mathrm{~d}$ 


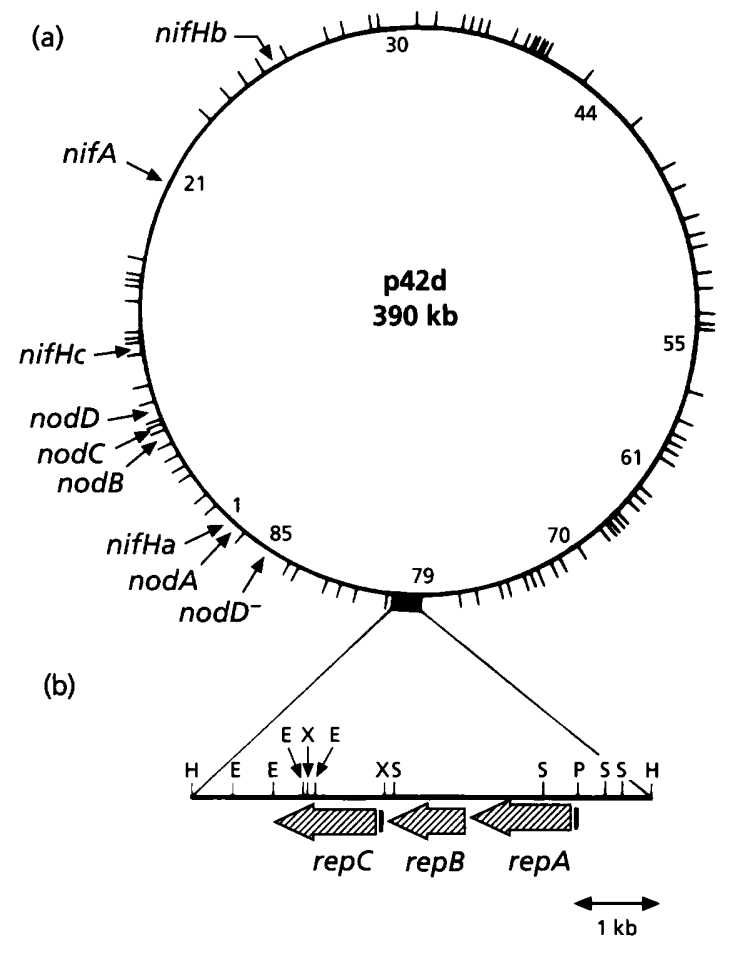

Fig. 2. (a) Circular map of plasmid p42d. The lines radiating from the circle represent BamHI restriction sites. Restriction fragments were numbered successively in a clockwise direction, starting with the fragment containing the nifHa gene. Arrows indicate the location of some nod and nif genes. The black box indicates the position of the replicator region. The map is drawn to a scale of $1 \mathrm{~kb}=0.93^{\circ}$. (b) The enlargement shows a restriction map of the $\mathrm{pH} 3$ insert. The orientation of the three ORFs is indicated by shaded arrows. Vertical black bars indicate the position in which putative Shine-Dalgarno sequences were found.

share regions of extensive homology. Tetracyclineresistant transconjugants were recovered with the complete set of cosmids when CE3 was the recipient strain but such transconjugants were obtained only with cosmid cGD47 when CFNX107 was used as receptor. Analysis of the plasmid profiles of CFNX107 containing cosmid cGD47 showed the presence of an additional small plasmid. Southern blot analysis confirmed that the new small replicon was indeed cGD47. When the same analysis was applied to transconjugants of CE3 two observations were made. Firstly, transconjugants containing cGD47 maintained the cosmid as an independent replicon but with the concomitant loss of the symbiotic plasmid, and secondly, transconjugants with the other cosmids were the result of co-integration events.

These results demonstrate that cGD47 contains the DNA regions involved in replication and incompatibility. Supported by the fact that only one cosmid was capable of independent replication, we concluded that the symbiotic plasmid contains only one replicator region in contrast to the megaplasmid pSym-b of Sinorhizobium meliloti which contains more than one origin of replication (Margolin \& Long, 1993).
Characterization of the replicator region of symbiotic plasmid p42d

On the basis of the restriction map, the estimated length of cGD47 is $39.8 \mathrm{~kb}$ comprising nine BamHI fragments, from fragment 72 to fragment 80 of the physical map of plasmid p42d (Girard et al., 1991). Each of these fragments was subcloned in vector pSUP202 and transferred to strains CFNX107 and CE3. Only clone pB79, which carries Bam HI fragment $79(16.8 \mathrm{~kb})$, was capable of independent replication in the CFNX107 background. However, when plasmid profiles of CE3 transconjugants containing pB79 were analysed, no new replicon was found, indicating that $\mathrm{pB} 79$ had integrated into the genome of the recipient strain. These data demonstrate that the replicator region of $\mathrm{p} 42 \mathrm{~d}$ resides in $B a m \mathrm{HI}$ fragment 79 but suggest that DNA sequences that lie outside of this fragment are required to avoid integration in a wild-type background and that $\operatorname{rec} A$ plays an important role in the establishment of incoming plasmids.

The insert DNA of plasmid pB79 has six HindIII fragments and each was subcloned into pSUP202 and introduced by conjugation into strains CFNX107 and CFNX101. Plasmid pH3, containing a HindIII fragment of $5.6 \mathrm{~kb}$, was capable of independent replication in both CFNX107 and CFNX101. Moreover, a plasmid profile analysis of the CFNX101 transconjugants showed that the symbiotic plasmid was absent. The different EcoRI, SalI and XhoI fragments of $\mathrm{pH} 3$ were tested individually and none were able to confer independent replication to pSUP202. From these experiments we concluded that the replicator and incompatibility functions of the symbiotic plasmid are restricted to the $5.6 \mathrm{~kb}$ HindIII fragment contained in pH3. Fig. 2(a) shows the location of the $5.6 \mathrm{~kb}$ HindIII fragment and the position of some nif and nod genes already sequenced on the circular map of $\mathrm{p} 42 \mathrm{~d}$. The HindIII restriction site downstream of $r e p C$ is located approximately $2.5 \mathrm{~kb}$ from the $\mathrm{Bam} \mathrm{HI}$ site boundary of fragments 79 and 80 . The $r e p A, r e p B$ and $r e p C$ genes are transcribed in a clockwise direction (as for the nifHDK operons of regions ' $a$ ' and ' $b$ '). Plasmid $\mathrm{p} 42 \mathrm{~d}$ is subject to frequent tandem amplifications in defined regions (amplicons). Usually boundaries of amplicons are reiterated sequences. The replicator of $\mathrm{p} 42 \mathrm{~d}$ is located in a region characterized by the presence of multiple reiterated sequences and the lack of tandem amplifications (Girard et al., 1991; Romero et al., 1995). As pointed out by Romero et al. (1995), this situation can be explained because a duplication of a sector containing the replicator may induce a delay in plasmid replication, due to a copy number control mechanism.

\section{Stability of cGD47, pB79 and pH3 plasmids}

By growing the cells in the absence of selective antibiotics at $30^{\circ} \mathrm{C}$, the stability of cGD47, $\mathrm{pB} 79$ and $\mathrm{pH} 3$ could be examined in the CFNX107 and CFNX101 genetic backgrounds. The results indicated that cosmid cGD47 and plasmids pB79 and pH3 are as stable as the 
symbiotic plasmid because no plasmid loss was observed in either background after 18 generations.

\section{Copy number of plasmid pH3}

To demonstrate that the replicator region contained in plasmid $\mathrm{pH} 3$ has the same properties as that of the symbiotic plasmid, the copy number of $\mathrm{pH} 3$ per chromosome of $\mathrm{p} 42 \mathrm{~d}$ was evaluated. Briefly, a Southern blot containing total DNA of strains CE3, CFNX101(pH3) and CFNX107(pH3) digested with HindIII was hybridized simultaneously with an internal fragment of the chromosome-encoded gene $\operatorname{rec} A$ and with an internal fragment of the $\mathrm{pH} 3$ insert as described in Methods. Each lane of the exposed film was evaluated by densitometry. In all three cases the plasmid/ chromosome ratio fluctuated between 1.3 and 1.6 , indicating that both replicons existed in the same copy number per chromosome.

\section{The nucleotide sequence of the $5.6 \mathrm{~kb}$ insert of $\mathrm{pH} 3$}

To examine the gene organization of the replicator region of the symbiotic plasmid, the complete sequence of the $\mathrm{pH} 3$ insert was determined. The sequence of the $\mathrm{pH} 3$ insert contained $5615 \mathrm{nt}$ and had three large potential ORFs on one strand (Fig. 2b). The DNA sequence and the putative translation products of the ORFs showed significant identity with $r e p A, r e p B$ and repC as described for the replicator regions from $R$. leguminosarum cryptic plasmid pRL8JI (Turner \& Young, 1995), A. tumefaciens plasmid pTiB6S3 (Tabata et al., 1989), A. rhizogenes plasmid pRiA4b (Nishiguchi et al., 1987) and Paracoccus versutus plasmid pTAV1 (GenBank U60522). Two putative ribosome-binding sites were found, one preceding $r e p A$ and the other preceding $r e p C$. Regions containing the $E$. coli promoter consensus [TTGACA $\left(\mathrm{N}_{17}\right)$ TATA C/A A/T] were not found, suggesting that these genes are not expressed in E. coli (Greener et al., 1992).

The four replicators described above and the $R$. etli replicator described here have the same genetic organization: the repA gene precedes $\operatorname{rep} B$ and repB precedes $r e p C$. Two intergenic sequences were found, one between $r e p A$ and $r e p B$ and the other between $r e p B$ and repC. Comparisons between the sequence of the replicator regions mentioned above showed that the replicator region of $\mathrm{p} 42 \mathrm{~d}$ is very closely related to that of plasmid pRiA4b.

Studies of the replicator region of plasmid pTiB6S3 demonstrated that genes rep $A$ and $r e p B$ encode proteins that are required for the stability of the plasmid but are not essential. BLAST analysis showed that the $\operatorname{rep} A$ and $r e p B$ gene products have some similarity with proteins required for the partitioning of $\mathrm{P} 1$ and $\mathrm{F}$ plasmids (Williams \& Thomas, 1992). Sequence comparisons with the complete sequence of other repA gene products showed that RepA of $\mathrm{p} 42 \mathrm{~d}$ is closely related to the repA gene product of pRiA4b with an identity of $92 \%$.

Sequence comparisons indicate that repB gene products are also conserved but the highest degree of identity was found in the central region of the proteins, suggesting that this region contains the functional domain for the stability function.

Surprisingly, the product of the $\operatorname{rep} C$, the principal product associated with the replication function, is less conserved. Comparison of the different complete RepC sequences showed identities between 27 and $73 \%$ with pRmeGR4a and pRiA4b, respectively. The hydrophobicity patterns (Kyte \& Doolittle, 1982) of the different RepC proteins were similar, suggesting that the three-dimensional structure of these proteins is conserved (data not shown). The wide variation observed for repC gene products is perhaps required to allow compatibility as suggested by Turner $e t$ al. (1996).

It has been suggested that the intergenic sequence between $r e p B$ and rep $C$ participates as an incompatibility determinant (Tabata et al., 1989). Sequence alignments of the intergenic sequence, including that between ORF2 and repC of plasmid pRmeGR4a of $S$. meliloti, showed regions of sequence conservation, including an AAAGAAAA motif present in all intergenic sequences. This motif may be important in the transcription of $r e p C$ or as a recognition sequence for a protein involved in incompatibility functions. The highest similarity was found with the intergenic sequence of pRiA $4 \mathrm{~b}$ of $A$. rhizogenes with $93 \%$ similarity in a 152 bp overlap.

\section{Occurrence of p42d-like replicator sequences in other Rhizobium species}

Plasmid profiles of $R$. huakuii, R. leguminosarum bv. viciae, $R$. loti, R. tropici, S. meliloti and several R. etli strains having different geographic origins were hybridized against the $\mathrm{pH} 3$ insert to assess whether related sequences are present in plasmids of other species (Fig. 3). Only six of the twelve strains tested contained a plasmid with homology to the replicator region of symbiotic plasmid $\mathrm{p} 42 \mathrm{~d}$, and in five cases the detected plasmid corresponded to a $R$. etli symbiotic plasmid (previously determined to be symbiotic plasmids by hybridization against a nifH probe; data not shown). In $R$. tropici the hybridization signal was detected in the smallest non-symbiotic plasmid. Moreover, the symbiotic plasmid of $R$. tropici CFN299 contains a repC type A gene similar to those described for $S$. meliloti (Burgos et al., 1996). Plasmid pH3 is autonomously replicated in the plasmid-less A. tumefaciens GM19023, indicating that the replicator of $\mathrm{p} 42 \mathrm{~d}$ is functional in other species (data not shown).

The fact that $\mathrm{p} 42 \mathrm{~d}$-like sequences were always found in symbiotic plasmids of $R$. etli strains of different geographic origins together with the high degree of homology detected in several $R$. etli symbiotic plasmids when hybridized against cosmids of the $\mathrm{p} 42 \mathrm{~d}$ symbiotic plasmid covering the whole plasmid suggests a monophyletic origin for the symbiotic plasmids of $R$. etli (Rodríguez et al., 1993). The study of the genetic basis of replication, mobilization and incompatibility of the plasmids will give us a better understanding of the rules 


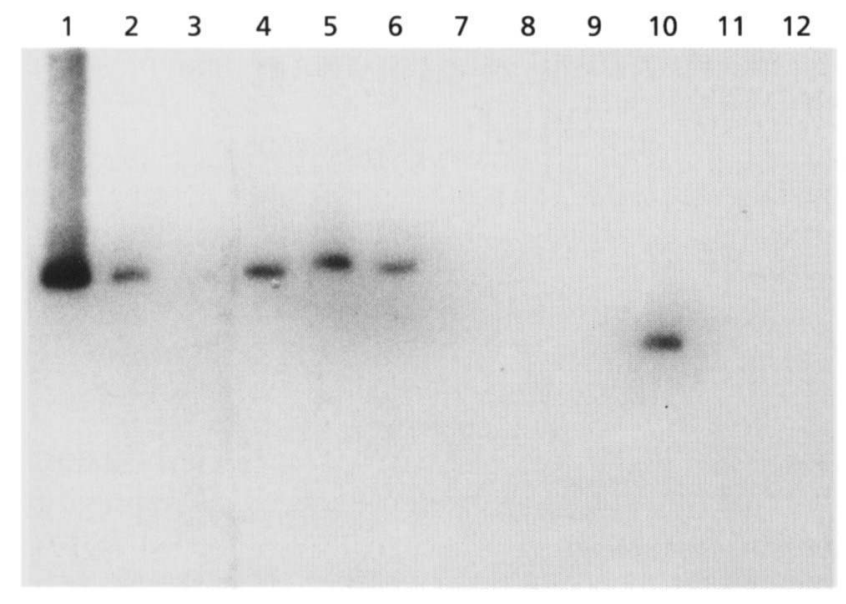

Fig. 3. Autoradiogram of plasmid profiles hybridized with $\mathrm{pH} 3$ insert demonstrating the presence of DNA homologous to the p42d replicator region in different Rhizobium strains. Lanes: 1 , $R$. etli CE3; $2, R$. etli BRA5; 3, Rhizobium spp. CIAT895; 4 , $R$. etli NITRAGIN8251; 5, $R$. etli TAL182; $6, R$. etli VIKING1; 7, $R$. huakuii CCBAU2605; 8, R. leguminosarum bv. viciae VF39; 9 , R. loti CIAM1810; 10, R. tropici CFN299; 11, S. meliloti, 2011; 12, R. et/i CFNX107 (a pSym-cured derivative).

governing horizontal plasmid transfer and hence a better picture of how the bacterial populations evolve.

\section{ACKNOWLEDGEMENTS}

We are grateful to David Romero for his critical comments, Sergio Caro for his skilful technical support, J. C. HernándezCelis for the use of data in the mapping of the replicator, Paul Gaytán and Eugenio López for the synthesis of oligonucleotides and José Espíriu for his assistance in the Computer Unit. We also thank Michael Dunn for reviewing the manuscript.

\section{REFERENCES}

Beynon, J. L., Beringer, J. E. \& Johnston, A. W. B. (1980). Plasmids and host range in Rhizobium leguminosarum and Rhizobium phaseoli. J Gen Microbiol 120, 421-429.

Boyer, H. W. \& Roulland-Dussoix, D. (1969). A complementation analysis of the restriction and modification of DNA in Escherichia coli. J Mol Biol 41, 459-472.

Burgos, P. A., Velázquez, E. \& Toro, N. (1996). Identification and distribution of plasmid-type A replicator region in Rhizobia. Mol Plant-Microbe Interact 9, 843-849.

Casse, F., Boucher, C., Julliot, J. S., Michel, M. \& Dénarié, J. (1979). Identification and characterization of large plasmids in Rhizobium meliloti using agarose gel electrophoresis. J Gen Microbiol 113, 229-242.

Ditta, G., Stanfield, S., Corbin, D. \& Helinski, D. R. (1980). Broad host-range DNA cloning system for Gram-negative bacteria: construction of a gene bank of Rhizobium meliloti. Proc Natl Acad Sci USA 77, 7347-7351.

Durland, R. H. \& Helinski, D. R. (1987). The sequence encoding the 43-kilodalton TrfA is required for efficient replication or maintenance of minimal RK2 replicons in Pseudomonas aeruginosa. Plasmid 18, 164-169.
García-de los Santos, A., Brom, S. \& Romero, D. (1996). Rhizobium plasmids in bacteria-legume interactions. World J Microbiol Biotechnol 12, 119-125.

Geniaux, E. \& Amarger, N. (1993). Diversity and stability of plasmid transfer in isolates from a single field population of Rhizobium leguminosarum bv. viciae. FEMS Microbiol Ecol 102, 251-260.

Girard, M. L., Flores, M., Brom, S., Romero, D., Palacios, R. \& Dávila, G. (1991). Structural complexity of the symbiotic plasmid of Rhizobium leguminosarum bv. phaseoli. J Bacteriol 173, 2411-2419.

Greener, A., Lehman, S. M. \& Helinski, D. R. (1992). Promoters of the broad host range plasmid RK2: analysis of transcription (initiation) in five species of Gram-negative bacteria. Genetics 130, 27-36.

Hanahan, D. (1983). Studies of transformation of E. coli with plasmids. J Mol Biol 166, 557-560.

Hooykaas, P. J. J., van Brussel, A. A. N., den Dulk-Ras, H., von Slogteren, G. M. S. \& Schilperoort, R. A. (1981). Sym-plasmid of Rhizobium trifolii expressed in different rhizobial species and in Agrobacterium tumefaciens. Nature 291, 351-353.

Hooykaas, P. J. J., den Dulk-Ras, H., Regensburg-Tuink, A. J. G., van Brussel, A. A. N. \& Schilperoort, R. A. (1985). Expression of a Rhizobium phaseoli Sym plasmid in R. trifolii and Agrobacterium tumefaciens: incompatibility with a $R$. trifolii Sym plasmid. Plasmid 14, 47-52.

Hynes, M. F., Brucksch, K. \& Priefer, U. (1988). Melanin production encoded by a cryptic plasmid in a Rhizobium leguminosarum strain. Arch Microbiol 150, 326-332.

Hynes, M. F., Simon, R. \& Puhler, A. (1985). The development of plasmid-free strains of Agrobacterium tumefaciens by using incompatibility with a Rhizobium meliloti plasmid to eliminate pAt C58. Plasmid 13, 99-105.

Johnston, A. W. B., Hombrecher, G., Brewin, N. J. \& Cooper, M. C. (1982). Two transmissible plasmids in Rbizobium leguminosarum strain 300. J Gen Microbiol 128, 85-93.

Kinkle, B. K. \& Schmidt, E. L. (1991). Transfer of the pea symbiotic plasmid pJB5JI in nonsterile soil. Appl Environ Microbiol 57, 3264-3269.

Kyte, J. \& Doolittle, R. F. (1982). A simple method for displaying the hydropathic character of a protein. J Mol Biol 157, 105-132.

Margolin, W. \& Long, S. (1993). Isolation and characterization of a DNA replication origin from the 1,700 -kilobase-pair symbiotic plasmid pSym-b of Rhizobium meliloti. J Bacteriol 175, 6553-6561.

Martínez, E., Romero, D. \& Palacios, R. (1990). The Rhizobium genome. Crit Rev Plant Sci 9, 59-93.

Martínez-Salazar, J., Romero, D., Girard, M. L. \& Dávila, G. (1991). Molecular cloning and characterization of the $\operatorname{rec} A$ gene of Rhizobium phaseoli and construction of recA mutants. J Bacteriol 173, 3035-3040.

Mercado-Blanco, J. \& Olivares, J. (1993). Stability and transmissibility of the cryptic plasmids of Rhizobium meliloti GR4. Arch Microbiol 160, 477-485.

Nishiguchi, R., Takanami, M. \& Oka, A. (1987). Characterization and sequence determination of the hairy root inducing plasmid pRiA4b. Mol Gen Genet 206, 1-8.

Noel, K. D., Sánchez, A., Fernández, L., Leemans, J. \& Cevallos, M. A. (1984). Rhizobium phaseoli symbiotic mutants with transposon Tn5 insertions. J Bacteriol 158, 148-155. 
O'Connell, M. P., Dowling, D., Neilan, J., Simon, R., Dunican, L. K. \& Puehler, A. (1984). Plasmid interactions in Rhizobium: incompatibility between symbiotic plasmids. In Advances in Nitrogen Fixation Research, p. 713. Edited by C. Veeger \& W. E. Newton. The Hague: Nijhoff Junk.

O'Connell, M.P., Hynes, M. F. \& Puehler, A. (1987). Incompatibility between a Rhizobium Sym plasmid and $\mathrm{Ri}$ plasmid of Agrobacterium. Plasmid 18, 156-163.

Pinero, D., Martínez, E. \& Selander, R. K. (1988). Genetic diversity and relationships among isolates of Rhizobium leguminosarum biovar phaseoli. Appl Environ Microbiol 54, 2825-2832.

Quinto, C., de la Vega, H., Flores, M., Fernández, L., Ballado, T., Soberón, G. \& Palacios, R. (1982). Reiteration of nitrogen fixation gene sequences in Rhizobium phaseoli. Nature 299, 724-726.

Rodríguez, O., Girard, M. L. \& Dávila, G. (1993). Structure and evolution of the symbiotic genomes of Rhizobium phaseoli. In New Horizons in Nitrogen Fixation, p. 646. Edited by R. Palacios, J. Mora \& W.E. Newton. Dordrecht: Kluwer Academic Publishers.

Romero, D., Martínez-Salazar, J., Girard, L., Brom, S., Dávila, G., Palacios, R., Flores, M. \& Rodríguez, C. (1995). Discrete amplificable regions (amplicons) in the symbiotic plasmid of Rhizobium etli CFN42. J Bacteriol 177, 973-980.

Romero, D., Dávila, G. \& Palacios, R. (1997). The dynamic genome of Rhizobium. In Bacterial Genomes: Physical Structure and Analysis, pp. 153-161. Edited by F. J. de Bruijn, J. R. Lupski \& G. Weinstock. New York: Chapman and Hall.

Rosenberg, C. \& Hughet, T. (1984). The pATC58 of Agrobacterium tumefaciens is not essential for tumor induction. Mol Gen Genet 196, 533-536.

Sambrook, J., Fritsch, E. F. \& Maniatis, T. (1989). Molecular
Cloning: a Laboratory Manual, 2nd edn. Cold Spring Harbor, NY: Cold Spring Harbor Laboratory.

Schofield, P. R., Gibson, A. H., Dudman, F. W. \& Watson, J. M. (1987). Evidence for genetic exchange and recombination of Rhizobium symbiotic plasmids in a soil population. Appl Environ Microbiol 53, 2942-2947.

Simon, R., Priefer, U. \& Puhler, A. (1983). A broad host-range mobilization system for in vivo genetic engineering transposon mutagenesis in Gram-negative bacteria. Bio/Technology 1, 784-791.

Tabata, S., Hooykaas, P. J. J. \& Oka, A. (1989). Sequence determination and characterization of the replicator region in the tumor-inducing plasmid pTiB6S3. J Bacteriol 171, 1665-1672.

Turner, S. L. \& Young, P. W. (1995). The replicator region of the Rhizobium leguminosarum cryptic plasmid pRL8JI. FEMS Microbiol Lett 133, 53-58.

Turner, S. L., Rigottier-Gois, L., Power, R. S., Amarger, N. \& Young, P. (1996). Diversity of repC plasmid replication sequences in Rhizobium leguminosarum. Microbiology 142, 1705-1713.

Wheatcroft, R., McRae, G. D. \& Miller, R. W. (1990). Changes in the Rhizobium meliloti genome and the ability to detect supercoiled plasmids during bacteroid development. Mol PlantMicrobe Interact 3, 9-17.

Williams, D. R. \& Thomas, C. M. (1992). Active partitioning of bacterial plasmids. J Gen Microbiol 138, 1-16.

Young, J. P. W. \& Wexler, M. (1988). Sym plasmid and chromosomal genotypes are correlated in field populations of Rhizobium leguminosarum. J Gen Microbiol 134, 2731-2739.

Received 31 December 1996; revised 7 April 1997; accepted 11 April 1997. 